\title{
Leiomyoadenomatoid Tumor of the Uterus
}

\section{Uterus'un Leiomyoadenomatoid Tümörü}

\author{
Mary MATHEW, Garima GOEL
}

Department of Pathology, KMC, Manipal, KARNATAKA, INDIA

\begin{abstract}
Adenomatoid tumors are benign, usually small lesions with a predilection for the male and female genital tracts. In the female genital tract, they may be found within the wall of fallopian tubes or beneath the uterine serosa near the uterine cornu. The term leiomyoadenomatoid tumor is used to describe a variant of adenomatoid tumor with a prominent smooth muscle component. In the present case report we describe a rare case of leiomyoadenomatoid tumor which was incidentally found in a hysterectomy specimen performed for symptomatic fibroid.
\end{abstract}

We report a case of leiomyoadenomatoid tumor of the uterus in a 51 year old female who presented with symptomatic fibroid.

Extensive literature search has resulted in only 3 cases of leiomyoadenomatoid tumors of the uterus. We would like to report an additional case of this rare tumor.

Key Words: Adenomatoid tumor, Uterus, Smooth muscle
ÖZ

Adenomatoid tümörler erkek ve kadın genital sistemlerini tutma eğilimi gösteren benign, genellikle küçük lezyonlardır. Kadın genital sisteminde fallop tüplerinin duvarında veya uterus kornu'larından uterus serozası yakınında yerleşebilirler. Leiomyoadenomatoid tümör terimi düz kas komponenti baskın olan adenomatoid tümör varyantını tanımlamak için kullanılır. Burada sempomatik bir fibroid nedeniyle uygulanan bir histerektomi spesimeninde insidental olarak bulunan nadir görülen bir leiomyoadenomatoid tümör olgusu tanımlanmaktadır.

Semptomatik fibroid ile başvuran 51 yaşındaki bir kadın hastanın uterusundaki leiomyoadenomatoid tümör olgusunu sunuyoruz.

Ayrıntılı literatür incelenmesi uterusta sadece 3 olgu bulunduğunu göstermiştir. $\mathrm{Bu}$ nadir tümörü sunarak bu olgulara eklemekten memnuniyet duymaktayız.

Anahtar Sözcükler: Adenomatoid tümör, Uterus, Düz kas

\section{INTRODUCTION}

Adenomatoid tumors are benign mesothelial tumors that are usually found in the myometrium and fallopian tubes in females and epididymis in males (1). They have been observed in women in the age group between 30-72 years. These tumors are usually incidental findings in $0.1-1 \%$ of females, in whom the uteri are removed for various other indications (2). Uterine adenomatoid tumors are often associated with smooth muscle hypertrophy. In some cases, the prominence of smooth muscle component simulates a leiomyoma and the lesion is denoted as a "leiomyoadenomatoid tumor" (3). We describe a rare case of leiomyoadenomatoid tumor involving the uterus in a 51year-old female.

\section{CASE REPORT}

A 51-year-old woman came with a history of severe lower abdominal pain. On transvaginal ultrasonography a fibroid

Received : 14.11 .2009

Accepted : 28.12.2009 in the posterior wall of the uterus was noted. A diagnosis of symptomatic fibroid was made. Hysterectomy along with bilateral salpingo-ophorectomy was performed and the specimen was sent for histopathological examination.

Hysterectomy specimen with bilateral salpingoophorectomy was received. Grossly, the uterus showed multiple intramural and subserosal solid, grey white masses with a whorled appearance. The largest intramural mass was in the right posterior uterine wall and measured $4 \times 3 \times 3 \mathrm{cms}$. A polyp was visible in the endocervical canal and bilateral adnexae appeared unremarkable. A diagnosis of leiomyomata with endocervical polyp was made on gross examination.

Microscopically, the largest uterine mass showed hypertrophied fascicles of smooth muscle cells infiltrated by cuboidal and signet ring-like vacuolated cells with tubular formations (Figure 1). The remaining uterine masses

Correspondence: Garima GOEL

KMC, Manipal, Pathology, KARNATAKA, INDIA

E-mail: drgarima_80@yahoo.co.in_Phone: +911125555044 


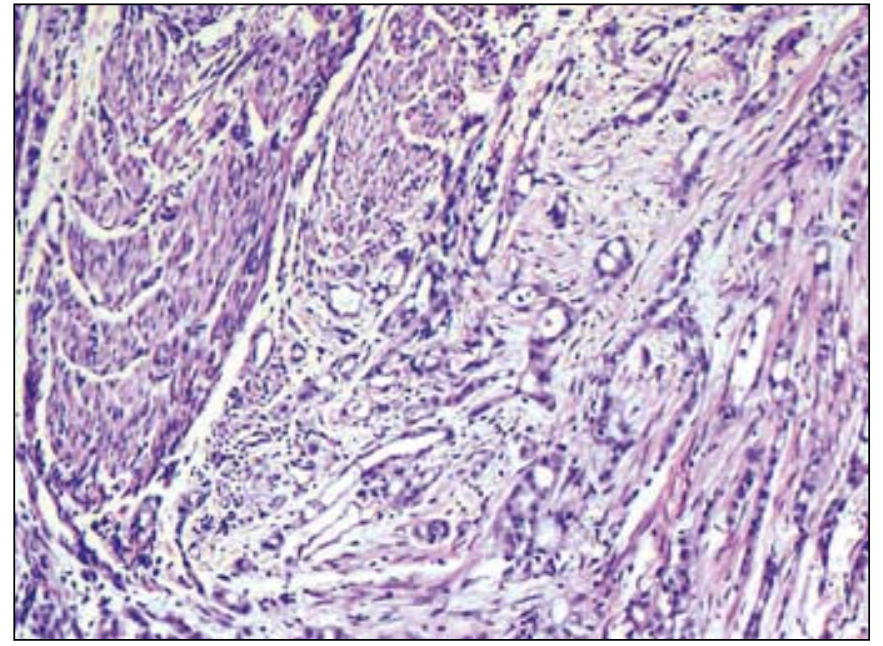

Figure 1: Vacuolated and signet ring cells in tubular formations along with hypertrophied smooth muscle bundles. (H\&E, x400).

showed interlacing and intersecting fascicles of smooth muscle bundles surrounded by scant hyalinized stroma. The endocervical polyp showed mucous glands surrounded by a cellular stroma with proliferating vessels. Both the ovaries and fallopian tubes showed unremarkable histology.

A diagnosis of leiomyoadenomatoid tumor of the uterus along with leiomyomata and endocervical polyp was made.

\section{DISCUSSION}

The term adenomatoid tumor was first proposed by Golden and Ash in 1945.(1) Adenomatoid tumors are generally considered to be of mesothelial origin and occur in organs close to mesothelium-lined surfaces. They are incidental findings in hysterectomy specimens of adult women, the incidence being approximately $1 \% .(1,2)$ These tumors are typically solitary, subserosal or myometrial masses, often located near the cornu and usually less than $4 \mathrm{~cm}$ in diameter.(4) They are often accompanied by leiomyomata and adenomyosis.(3)

Histologically, the tumor can have an adenoid, angiomatoid, solid or cystic architecture or a combination of more than one type. Some tumors, as in the present case, can have a prominent smooth muscle component.(3) The histogenesis of adenomatoid tumors was controversial and subject to debate, but ultimately it was proven by electron microscopic and immunohistochemical findings to be of mesothelial origin.(2) The tumor cells are strongly positive for cytokeratin, vimentin, calretinin and HBME-1 (antihuman mesothelioma antibody), but do not express EMA, CEA.(1-3)

The term "leiomyoadenomatoid tumor" was first described by Epstein in 1992 as a variant of adenomatoid tumor with a prominent smooth muscle component. Extensive smooth muscle overgrowth may sometimes obscure the adenomatoid tumor and result in a misdiagnosis of leiomyoma or malignant tumor infiltrating the smooth muscle bundles.(1,3) Various authors believe that these smooth muscle bundles either represent entrapped myometrium permeated by the adenomatoid tumor or due to reactive hyperplasia of indigenous myometrial smooth muscle.(1)

The differential diagnosis of adenomatoid tumors is usually not complicated due to its typical morphology.(4) However, they can be mistaken macroscopically for leiomyomas as in our case, or lymphangiomas if the tumor is cystically enlarged. Adenomatoid tumors with a diffuse infiltrative growth pattern have to be distinguished from malignant lesions such as metastatic signet ring cell adenocarcinoma, epithelioid hemangioendothelioma, germ cell tumor or sex cord stromal tumor.(2)

Cases of adenomatoid tumors in the uterus have been reported in the literature. However, extensive literature search has resulted in only 3 cases of leiomyoadenomatoid tumors of the uterus.(1-3) We would like to report an additional case of this rare tumor.

\section{REFERENCES}

1. Hong R, Choi DY, Choi SJ, Lim SC: Multicentric infarcted leiomyoadenomatoid tumor: a case report. Int J Clin Exp Pathol 2009, 2: 99-103

2. Bolat F, Kocer E, Bal N, Kucukgoz U: Adenomatoid tumor of the female genital tract: Report of three cases. Turk J Pathol 2007, 23: 98-102

3. Amre R, Constantino J, Lu S, Charney D: Pathologic quiz case: a 52-year-old woman with a uterine mass. Leiomyo-adenomatoid tumor of the uterus. Arch Pathol Lab Med 2005, 129: 77-78

4. Clement P, Oliva E: Mesenchymal lesions of the uterus. Histopathology 2002, 41: 12-31 